\title{
AGENT BASED SCIENCE TEACHING
}

\author{
Ronald N. GIERE \\ University of Minnesota
}

\section{Content Based Science Teaching}

In content based science teaching, the emphasis is on the effective teaching and learning of currently accepted scientific theories and experimental results. This is the type of science teaching one finds typicaly in college and university courses designed for majors and aspiring scientists_particularly in the natural and biomedical sciences.

The philosophy of science that encourages content based science teaching is positivism or Logical Empiricism. This approach to the philosophy of science emphasizes the logical analysis of the language of science, both the language of theories and of observation, in which the content of science is expressed. There is not much role for the cognitive siences in the approach to science teaching. About all that is relevant is extensions of traditional psychological research into theaching techniques appropriate to various sciences.

\section{Method based science teaching}

Here the emphasis is on the methods used to legitimate the accepted content of sience. Method based courses are typically found in pre-university education and lower division university courses not intended for science majors.

Several different philosophies of science could contribute to method based science teaching. One could appeal to logical empiricism, with its emphasis on 
formal, logical relations between evidence and hypotheses. One could also appeal to Pragmatism, which emphasized more general features of scientific method. One could even appeal to historical methodologies such as Imre Lakatos" "Methodology of Scientific Research Programmes" (1970) or Larry Laudan's «Problems Solving Methodology» (1977).

Method based science teaching also does not provide many opportunities for utilities for results of the cognitive science. The methods in question are typically defined in logical or otherwise "objective" terms having no reference to actual human cognition.

\section{Historically based science teaching}

Here the focus is on the actual historical processes that led to the currently accepted content of the science. Again, historically based courses are typically found in preuniversity education and lower division university courses not intended for science majors.

The philosophy of science aligned with historically based science teaching is that of the "historical school" which includes such 1960s figures as N.R. Hanson (1958), Thomas Kuhn (1962), and Stephen Toulmin (1972). It was the emergence of this school in the philosophy of science that has led some science educators since the 1960 s to consider seriously the history and philosophy of science as a resource for science education (Duschl and Hamilton, 1992).

Here, finally, we begin to find a place for the cognitive sciences. In historically based science teaching one looks at the historical actors, the scientists, who produced the scientific results we now have. Their cognitive processes are clearly relevant to the story. So, in exploring these processes, it is appropriate to employ the concepts and results of the cognitive sciences. Here I will note only one example.

Philosophers of science, such as Nancy Nerssessiean (1992. ${ }^{\text {) }}$, and science educators, such as John Clement (1982), have connected philosophical work on conceptual change with ideas about mental models developed in the cognitive sciences and applied the combination to science teaching. Their view is that science teaching is not just a matter of providing students with new information, as in a content based approach to science teaching. Rather, they argue, students at all levels come to the study of science with their own theories already in place. 
Physics students, for example, come to the study of physics is really a matter of inducing conceptual change. Anything we can learn from the cognitive sciences about conceptual change is potentially relevant.

\section{Agent based science teaching}

Here the focus is on (a) individual agents, (b) operating in a historical process, (c) utilizaing various methods, (d) producing scientific knowledge (content). An agent based approach to science teaching, therefore, incorporates components from the other approaches and integrates them in a single approach focusing on individual agents, be they scientists or students.

An agent based approach to science teaching goes naturally together with a cognitive approach to the philosophy of science. Scientists and science students, after all, are cognitive agents. Different philosophers of science, of course, emphasize different aspects of the cognitive sciences. Paul Churchland (1989), for example, focuses on the neurosciences; Nancy Nerssessian (1992b) on cognitive psychology; Paul Thagard $(1988,1991)$ on artificial intelligence. At the moment, I think we have most to learn from cognitive psychology (Giere, 1988, 1992, 1994), although nothing can be ruled out a priori.

\section{What about a socially based approach to science teaching?}

In recent years there have been major developments in the social studies of science. Should we attempt to incorporate this work into science teaching? To some extent, yes, but it should not be the focus of our approach to science teaching. An agent based approach assumes that scientists and students are cognitive agents. They are also human agents, cultural agents, economic agents, gendered agents, and so on. These roles all interact. So what scientists do as cultural agents influences, in all kinds of ways, what they do as cognitive agents. This fact should not be ignored by science teachers or hidden from science students. Sometimes, the best explanation of the acceptance, or rejection, of a scientific theory by scientists is to be found in their involvements in others roles within the broader society. A major focus on the social aspects of science, however, takes us too far from the methods and content that must retain a central role in science education. 


\section{Conclusion}

There is increasing interest among science educators in both the history and philosophy of science and in the cognitive sciences. The lesson of this brief note is that there are different approaches to science education, different approaches to the philosophy of science, and different approaches to cognitive science. The success of any combination will depend in large measure on how well the different approaches can be integrated. My own suggestion is that an agent based understanding of science education best integrates science education, philosophy of science and cognitive science.

\section{References}

Churchaland, P. M., (1989): A Neurocomputational Perspective: The Nature of Mind and the Structure of Science. Cambridge: MIT Press.

Clement, J. (1982): "Students' Precomceptions in Introductory Mechanics". American Journal of Physics, 50: 66-71.

DusCHL, R. A. and R. I. Hamilton, (1992): Philosophy of Science, Cognitive Psychology, and Educational Theory and Practice. Albany: State University of New York Press.

GIERE, R. N. (1988): Explaining Science: A Cognitive Approach. Chicago: University of Chicago Press.

Giere, R. N. Ed. (1992): Cognitive Models of Science. Minnesota Studies in the Philosophy of Science, vol. 15. Minneapolis: University of Minnesota Press.

Giere, R. N. (1994): «The Cognitive Structure in Scientific Theories». Philosophy of Science, 61: 276-296.

Hanson, N. R. (1958): Patters of Discovery. Cambridge: Cambridge University Press.

KuHN, T. S. (1962): The Structure of Scientific Revolutions. Chicago: University of Chicago Press (2 ${ }^{\text {nd }}$ ed. 1970).

LAKATOS, I. (1970): «Falsification and the Methodology of Scientific Research Programmes". In Criticism and the Growth of Knowledge. Eds. I.Lakatos and A. Musgrave, 91-195. Cambridge: Cambridge University Press.

Laudan, L. (1977): Progress and its Problems. Berkeley: University of California Press.

NERSESSIAN, N. (1992): "Constructing and Instructing: The Role of "Abstraction Techniques" in Creating and Learning Physics". In Philosophy of Science, Cognitive 
Psychology, and Educational Theory and Practice, 48-68. Eds. R.A. Duschl and R.I. Hamilton. Albany: State University of Ney York Press.

Thagard, P. (1988): Computational Philosophy of Science. Cambridge: MIT Press.

Thagard, P. (1991): Conceptual Revolutions. Princeton: Princeton University Press.

Toulmin, S. (1972): Human Knowledge. Princeton University Press. 